\title{
THE COLD PEACE: RUSSO-WESTERN RELATIONS AS A MIMETIC COLD WAR
}

Richard Sakwa

\section{University of Kent}

\begin{abstract}
In 1989-91 the geo-ideological contestation between two blocs was swept away, together with the ideology of civil war and its concomitant Cold War played out on the larger stage. Paradoxically, while the domestic sources of Cold War confrontation have been transcended, its external manifestations remain in the form of a 'legacy' geopolitical contest between the dominant hegemonic power (the United States) and a number of potential rising great powers, of which Russia is one. The post-revolutionary era is thus one of a 'cold peace'. A cold peace is a mimetic Cold War. In other words, while a Cold War accepts the logic of conflict in the international system and between certain protagonists in particular, a cold peace reproduces the behavioural patterns of a Cold War but suppresses acceptance of the logic of behaviour. A cold peace is accompanied by a singular stress on notions of victimhood for some and undigested and bitter victory for others. The perceived victim status of one set of actors provides the seedbed for renewed conflict, while the 'victory' of the others cannot be consolidated in some sort of relatively unchallenged post-conflict order. The 'universalism' of the victors is now challenged by Russia's neo-revisionist policy, including the defence not so much of Westphalian notions of sovereignty but the espousal of an international system with room for multiple systems (the Schmittean pluriverse).
\end{abstract}

The world today faces enormous threats as the organisations and systems established to manage the Cold War order become increasingly dysfunctional in the post-Cold War era, and indeed to some degree these institutions themselves generate a state of affairs that we shall call a 'cold peace'. ${ }^{1}$ At the heart of the contemporary cold peace are Russo-Western relations, which remain in a no-man's-land in which there is neither the full-scale creation of a new political community nor an openly acknowledged conflictual relationship. If a Cold War is one that the immediate participants fear to fight directly, although ready to engage in any number of proxy wars, a cold peace is a far more fragile system of international order. A cold peace is an unstable geopolitical truce in which the fundamental problems of a post-conflict international order have not been resolved. While a Cold War accepts the logic of competition, a cold peace proceeds on the assumption that problems have been resolved, and this assumption itself becomes the cause of renewed conflict since it seeks to embed a particular hegemonic formation as universally applicable for all. In keeping with the liminal status of Russo-Western

\footnotetext{
${ }^{1}$ I am grateful for the exceptionally detailed and helpful comments of the anonymous reviewers.
} 
relations, interactions veer between the cooperative to the antagonistic, with an unstable combination of both mostly operating simultaneously. No party wishes to repudiate the possibility of greater co-operation, but neither is able to repudiate the sources of the antagonism.

\section{What is a cold peace?}

In certain respects the interwar period from 1918 was a cold peace, and its failings led to renewed global conflict in 1939 (cf. Ikenberry 2001). It was not just Germany that was treated as a defeated power, since following the Great War Soviet Russia was also excluded from the congress of the victors. Equally, it appeared that after the end of the Cold War post-communist Russia appeared too often a superfluous, and troublesome, accessory to the new dispensation. Russia is at the heart of the cold peace, although the cold peace encompasses problems that are not confined to a single country (Korinman and Laughland (eds) 2008). Like the Cold War, ultimately the cold peace is a global problem with global implications. In its first years of independence after 1991 Russia was essentially a status quo power, although from the first there were clear signs that the dominant elite interpretation of post-Cold War international order differed significantly from that prevalent in the Western community. In the West the universalistic normative values of democracy and human rights were associated with the enlargement of an existing geopolitical formation. For a brief period during Mikhail Gorbachev's 'New Thinking' and in the very early stage of post-communism, this view was compatible with Russia's own aspirations. Andrei Kozyrev, Russia's first foreign minister, insisted that Russia had no national interests outside of 'all-human values'. This period has been dubbed 'romantic' but it might better be characterised as idealistic. It sought to base policy on a set of universal ideals based on human rights, national self-determination, and the belief that the end of the Cold War was a common victory. Soviet ideology gave way to a democratic idealism, and policy remained removed from the harsh geopolitical realities of the world in which the newly-independent Russian state found itself.

This idealistic phase did not endure long. Already in Stockholm on 14 December 1992 Kozyrev administered an alarming dose of 'shock diplomacy' when he adopted a faux persona and delivered an address to the Conference on Security and Co-operation in Europe (CSCE), including NATO foreign ministers, mimicking the attitudes of the 'old thinking'. He threatened to use force against other former Soviet republics and accused NATO of interfering in its back yard. He described former Soviet territory as 'a postimperial space where Russia has to defend its interests by all available means, including military and economic ones' ('Diplomats Shocked by Kozyrev Ploy', 1992). The intention was to make the delegates aware of what they could expect if they continued with their perceived uncooperative policies towards Russia. The charade in the event turned into a very real premonition of what would in due course become the cold peace. The incident demonstrates that Russia, although naively and certainly idealistically, was already prepared to challenge the prevailing modalities of international order. The acting out of possible scenarios only reinforced the liminal nature of the period, and suggests that there was nothing predetermined about the way that Russia developed later. This attempt to demonstrate the danger of slipping back into a renewed era of confrontation 
was vitiated by the other powers, and international politics soon settled back into customary patterns.

This early phase, however, demonstrates that Russia, however naively and certainly idealistically, tried to challenge the prevailing modalities of international order, an episode that suggests that there is nothing predetermined about the way that Russia developed later. This attempt was vitiated by the other powers, and international politics soon settled back into customary patterns.

As part of a renewed assertiveness, Kozyrev went on to argue that Russia could be a democratic post-Cold War great power pursuing a non-ideological definition of national interests while accepting that this could sometimes entail elements of competition with the West. This tough approach was vividly manifested in his refusal in November 1994 in Brussels to sign documents already agreed with NATO concerning the Partnership for Peace (PfP) programme. Attempts by the West to discredit the pursuit of Russia's 'normal' great power interests by forever raising the spectre of a revival of the Cold War, according to Boris Yeltsin a month later at the Budapest summit of what became at that time the Organisation for security and Co-operation in Europe (OSCE), threatened precisely to lead to the emergence of a 'cold peace' (Kozyrev, 1995). There had thus been a window of opportunity in which the Cold War could have been transcended to establish a new dynamic in Russo-Western relations. Instead, on both sides attitudes hardened, and an extended period of cold peace ensued. Russia returned to its traditional aspirations to be a great power of a very specific type (the question of derzhavnichestvo is examined by Ortmann 2011; for a historical discussion, see Rich 2009). The cold peace is characterised by powerful inherent tensions and endlessly iterated clashes of perceptions and misperceptions as Russia seeks to find its place in an unforgiving international system (Clunan 2009).

The tensions accompanying the search for a new relationship between Russia and what is conventionally called the West (internal differentiation will not be examined here) gave rise ultimately to a growing strain of what I we call neo-revisionism. This differs from traditional ideas of revisionism, since Russia makes no claim to revise the existing international order, but in a paradoxical inversion of the original Helsinki process, demands that the leading powers abide by the mutually-established rules of the international system, as well as claiming a no less leading place in that system. It is for this reason that Russia is far from being a consistently revisionist power, and thus much of the literature on bandwagoning and balancing, while entirely relevant, needs to be seen in context. Russia is a neo-revisionist power, happy (for the time being at least) to endorse American hegemony as long as what it perceives to be its vital interests and prestige are acknowledged. A superpower creates alliances rather than joins them and generates norms rather than obeys them, and Russia's reduced status certainly cannot be placed in that category and thus stands in an ambiguous relationship with both alliances and norms.

Russia's endless quest to be recognised as a great power reveals its own ambivalence over whether it is worthy of the status. Like Japan a generation ago, Russia remains what Shogu Suzuki calls a 'frustrated great power' (Suzuki 2008). China also finds itself in this category. Its 'quiet rise' is now accompanied by some noisy expressions of the assertion of sovereignty-centred view of international politics. As becomes the longest continuously-existing state in the world, it will let no one else 
determine the appropriate standards of civilisation. As Perry Anderson notes in a brilliant recent essay, "If the twentieth century was dominated, more than by any other single event, by the trajectory of the Russian Revolution, the twenty-first will be shaped by the outcome of the Chinese Revolution' (Anderson 2010, 59). The West's relations with China moved from 'cold war' and since the 2000s has increasingly assumed the character of a cold peace, but the dynamics of that particular case is not the subject of this paper.

In broad terms a cold peace can be described as an unstable geopolitical truce, typically found in inter-war periods, where the 'defeat' of the one side is not accepted as legitimate, while the 'victory' of the other side cannot be consolidated. Thus in certain respect the twenty years' crisis of the inter-war years, described by E. H. Carr in his book of that title (2001), can be described as an example of a cold peace. Few if any of the fundamental structural problems facing European and global security were resolved at that time, provoking in the end a renewed bout of conflict, prefigured by Japan's invasion of Manchuria in 1931 and the onset of the Spanish civil war in 1936. A cold peace is a mimetic Cold War. In other words, while a Cold War accepts the logic of conflict in the international system and between certain protagonists in particular, a cold peace reproduces the behavioural patterns of a Cold War but suppresses acceptance of the logic of that behaviour.

A cold peace is accompanied by a singular stress on notions of victimhood for some and undigested and bitter victory for others. The perceived victim status of one set of actors provides the seedbed for renewed conflict, while 'victory' cannot be consolidated in some sort of relatively unchallenged post-conflict order. The reappraisal of the past becomes 'historical revisionism', a term that has both a neutral scholarly meaning as the reappraisal of the past in the light of new evidence, but it can also mean the attempt to rewrite history in the light of current political concerns accompanied by the distortion or suppression of essential historical facts (Kopeček (ed.) 2008). The whole post-communist world is now engaged in a frenzy of historical revisionism, in both senses of the term, as each newly independent state creates the appropriate national narratives. Certain cases have become exemplary, notably the debate over the Holodomor (the man-made famine) in Ukraine in the early 1930s, and the background to the NaziSoviet Pact of August 1939 and the subsequent incorporation of the Baltic republics into the Soviet Union. A number of post-communist countries present their recent sufferings as 'genocides', notably in the Baltic states, the Caucasus and Ukraine, which then become the subject of international politics in the form of recognition/denial disputes (Finkel 2010). The blanket condemnation of the communist experience, without shade or nuance, is symptomatic of this attempt to 'other' not just the geopolitical influence of the Soviet Union and now Russia, but also to render each country's own past as somehow alien to the current order and an aberration from some essentialist definition of national identity. The politicisation of history is one of the defining features of a mimetic Cold War as battles between historians reveals the suppressed violence between the protagonists.

The problem of historical assessment gains added valence at times when the bases of social order changes, and thus the appreciation of the national narrative changes to sustain contemporary needs. As Greenleaf and Golburt put it, 'A preoccupation with memory arises when fear of amnesia is in the air' (2009, 744). Russian history is 
characterised by repeated cycles of repression and censorship which has fostered 'a conception of memory as a heroic act of consciousness', but in addition to this 'dissident' narrative memory studies in Russia today draw on aspects of daily life and material culture to provide an account of how power is embedded in everyday practices. Contemporary memory studies have a strongly mimetic component, defined as 'those aspects of memory that consciously or unreflectively represent the past precisely by repeating its patterns as well as the narrative commonplaces of its commemoration'. Thus the mimetic component of remembering is focused on the 'repetitive cultural rituals, formal traditions, and bodily habits that cause past experience to be replicated in the present as "second nature" - not as heroic or transcendent acts of consciousness" (Greenleaf and Golburt 2009, 744). In the Russian context this takes on a deeper meaning since the whole history of Russia's engagement with Western modernity has been accompanied by a permanent fear of adaptive mimesis: that its own 'authentic' identity would be lost as it not only copied Western models of development but denigrated its own customs. The revolt against universalising discourses reflects an innate Platonic conception of mimesis as mere imitation and estrangement from truth and reinforces the search for a genuinely original Russian tradition in art and politics. ${ }^{2}$

This is precisely the distinction drawn in nineteenth century Germany between Kultur and Zivilisation; one as authentic while the other is adaptive and mimetic. This is the dilemma that faces all late developing societies as the model of modernity is established elsewhere. The tension between adaptation and particularity, typically taking the form of the endlessly repeated Westerniser/Slavophile meme, reveals that contemporary Russia remains locked in a permanent catch-up cycle while desperately looking for an alternative. A cold peace is thus rooted in incommensurable understanding of the specificity of a particular historical epoch. For some it is savoured as a victory, accompanied by rhetoric about building a land 'fit for heroes' or representing the 'end of history' when the belief system of the victors is generalised as universally applicable to all. For others, it is a period of loss and disorientation, in which resentment against the triumphalism of the self-declared victors is nurtured and the institutions in which the alleged victory is consolidated are execrated.

A cold peace, like a Cold War of which it is the mimetic twin, is based on an implacable axiological logic: that is, a quasi-Gnostic appreciation of good and evil, rather than a more pluralistic understanding of the contingent and culturally constructed nature of social order (Rossbach 1999). A cold peace is not simply the reproduction of dualism in ideology and bipolarity in the state system, but a set of deeply embedded but opposed value systems, each rooted in a geopolitical vision of its own, accompanied by the denigration of the other as somehow civilisationally less valid and legitimate, if not civilisationally less competent (Sztompka 1998). Mimesis indeed is a form of learning where one society begins by copying another and thus gradually adapts its norms and standards of behaviour. The 'other' in that context is reduced to the status of 'pupil', and the dominant power becomes the teacher (Prozorov 2006). Thus the mimetic character of the cold peace also contains a socialising function, and this is reflected in the neorevisionist character of contemporary Russia: not entirely set against the existing order,

\footnotetext{
${ }^{2}$ For Aristotle mimesis plays a more positive role, comparable to a child learning by mimicry and for humanity as a whole, as Charles Darwin stressed, it is a tool for learning about the empirical reality of the outside world. See Greenleaf and Golburt, 'Introduction', pp. 744-5.
} 
yet undergoing a painful process of mimetic adaptation in a competitive, but not typically conflictual, geopolitical environment.

\section{The cold peace in practice}

The contemporary cold peace is characterised by numerous features. Above all, Russia's assertion of the ideology of 'multipolarity' is implicitly directed against the putative unipolar hegemony of the remaining superpower, the United States, accompanied by stress on the need for 'equality' between the great powers. Much of this rhetoric is reminiscent of the strident claims made by Germany and Japan as they sought to justify their entry into an already crowded international system in the period before the Great War.

Russia's relative isolation and competition with the West (although this competition, as noted above, is accompanied by a learning and socialisation process), above all with the United States and Britain, has provoked a search for new partners, notably China and India, as well as gestures to countries like Venezuela under Hugo Chávez. These initiatives are an attempt to create some sort of mimetic balancing order: one that does not genuinely threaten the existing hegemonic great powers, but signals Russia's dissatisfaction with that dominance. It also tries to build alliances on the basis of 'legacy' relationships, notably by re-establishing links with former partners, notably Cuba and Syria, and even to a degree with Vietnam. This is complemented by the development of closer ties with medium-rank powers such as Turkey and Brazil. Russia has become the potential core of a new 'union of the outsiders', with Turkey a privileged member of this club as its 'neo-Ottoman' ambitions in the Middle East and elsewhere develop (Sakwa 2010).

There are also attempts to consolidate post-Soviet space into Russian-sponsored integration projects, a region-building endeavour that counteracts but which could also complement that of the European Union (EU). The Commonwealth of Independent States (CIS) and the Russian-Belarusian union are complemented by the more effective Cooperative Security Treaty Organisation (CSTO) and the Customs Union, while Putin's declaration in October 2011 in favour of the creation of a Eurasian Union signalled that integration projects in post-Soviet Eurasia would be his priority in his third term as president (Putin 2011a). This is accompanied by opposition to former Soviet countries (excluding the Baltic republics) joining western-centred security bodies, above all NATO (Freire and Kanet (eds) 2010). A competitive dynamic in the post-Soviet space is assumed by both sides, while neither wishes to enter into open conflict, let alone military hostilities, with the other. Again, this can be described as a mimetic reprise of the 'great game', where the forms of rivalry are re-enacted but without the spirit of desperation that characterised the original in the nineteenth century.

In the immediate post-1945 years Russia (in its Soviet guise) was faced by a choice between some sort of domestic thaw accompanied by international integration, or the maintenance of domestic repression and international hostility (Gorlizki and Khlevniuk 2004). The country took the latter path. After 1991 Russia was faced with a similar, although far less stark, choice, which could be posed as between liberal democracy and international integration, or the restoration of a traditional authoritarian regime. Society was once again suffocated by the state, and modernisation programmes 
relied on state intervention from above and were unable to release the full potential of modernisation from below, or indeed the middle, by releasing entrepreneurial energy freed from the clammy hand of the bureaucracy, accompanied by rampant corruption and insecure property rights (Frye 2010). The contemporary cold peace is indeed accompanied by the tension between liberal domestic development and the assertion of perceived great power interests (Neumann 2008). The fact that such a systemic tension persists indicates the structural roots of the problem.

The structural nature of the cold peace lies in part in issues of status and dignity. Only Russia (and possibly Serbia) endured a major perceived geopolitical loss at the end of the Cold War, accompanied by the assumed denigration of national dignity (Tsygankov 2012). In this context, even minor slights by the major powers can provoke an exaggerated response, while challenges, such as the placing of a third tier ABM system in Poland and the Czech republic, accompanied by plans to extend NATO into the heartlands of Russia's historic statehood in Ukraine, as well in Georgia, was seen to represent not only a systemic challenge to Russia's great power aspirations, but an existential threat to Russia's very existence. ${ }^{3}$ NATO declarations that enlargement does not threaten Russia's security suppresses recognition of the insecurities generated by what indeed is not intended to be a threat. This blindness prompted Russia's military response over South Ossetia and Abkhazia in August 2008, a conflict which Russia felt it had to fight if it were to be taken seriously as a power at all (Asmus 2010; Cornell and Starr (eds) 2009; and for a more balanced analysis, Hamilton 2009).

As far as the Western powers are concerned, the cold peace emerged out of Russia's democratic backsliding (the systemic explanation for the cold peace). Changes in Russia's domestic environment from this perspective throw doubt on its credentials as a fully paid-up member of the Western-led international community. Immediate concerns about the stability of Russia's democratic institutions and the persistence of democratic practices quickly spill over into questions about the availability of a political culture of democracy, and indeed about Russia's civilisational identity as a member of the Western community of nations (Tsygankov 2007, 2008). These questions gained added force when Russia sought to reassert itself in spheres where it considered it had legitimate interests. Russia's response - that democracy was an internal matter and the pace of Russia's transition was not something to be judged by outsiders - was not one to increase the confidence of Western partners. Thus the cold peace is characterised by a negative dynamic: internal consolidation delegitimated external assertion; while external assertiveness seems only to demonstrate democratic retrenchment at home and a way of imposing an artificial consensus. Differences between mature democratic countries do not typically spill over into confrontation, whereas with countries whose relationship is characterised by a cold peace, conflict is an ever-present reality.

\section{Russia and the problem of post-Cold War international order}

When 'Russia' was great it was not Russia; when it was Russia, it was not great. Although not entirely true, this apothegm reveals one of the central paradoxes of contemporary Russia. For two centuries before 1917 Russia was officially termed an empire, thus

\footnotetext{
${ }^{3}$ This is the way Medvedev described it to the members of the Valdai International Discussion Club on 12 September 2008, personal notes.
} 
explicitly denoting an entity that in terms of the multiplicity of its peoples and its political order was something other than the nation-states that were beginning to emerge elsewhere in Europe. Russia was officially the core of the Russian Empire and the heart of the Tsarist autocracy, and as a nation-state it barely existed (Hosking 1997). After 1917 for some seventy years Russia the subject once again in effect disappeared, subsumed officially into a larger entity called the Union of Soviet Socialist Republics (USSR) from 1922 to 1991. The Russia that emerged in 1991 was in many respects an entirely new country: its borders corresponded neither with the ethnic settlement of Russians in the former Soviet space nor with the historic contours of a previous state. The essential ambiguity about Russia's status as a nation and over the character of the state spills over into the country's relations with the rest of the world (Shevel 2011).

\section{Continuers versus innovators}

The post-Cold War era is based on a fundamental division of opinion. On the one hand there are those who can be dubbed 'continuers', who argue that despite the end of the Cold War the institutions of the West European security community should be stretched to the East, representing in their view the extension of the zone of peace and prosperity that had been nurtured in their shade for half a century. Such an approach eschews mimetic adaptation, since the process is largely one of mechanical adoption of an existing set of rules, even though they may have been devised in different times for different purposes. For most East European countries this mechanical appropriation of an existing legacy was relatively unproblematic and coincided with their self-image as 'Western' and their post-communist programme of the 'return to Europe'; but for the bulk of the postSoviet states there could be no such easy transfer. Russia would inevitably be the core of an alternative region-building endeavour if it wished to be 'Russia', as traditionally understood in terms of the continuer state to the Russian empire and the Soviet Union. The two types of continuation represent a deeper sub-text to the cold peace.

Andrew Cottey (2007) is one of the most eloquent defenders of the Western continuer point of view. He argues that the European security community (encompassing the EU and NATO) embodies a pattern of behaviour which has demilitarised relations between its members, and European states no longer consider each other military adversaries. This represents a qualitative change in European affairs, and its achievements in Cottey's view should not wantonly be squandered. Wars in Yugoslavia and various conflicts in the former Soviet Union only reinforced the relevance of the European security community. The West European zone of peace could be extended by a policy of patient but persistent conditionality that would gradually socialise the periphery to the values of the core. Thus the European system represents a crucial part of the Atlantic security order with a logic and rationale of its own. There are growing problems, however, since the EU increasingly imbues the European security order with its values, if not its norms, and thus there is a potential divergence with the militarism that is at the core of NATO's mission.

The threats to the European system include the proliferation of weapons of mass destruction, radical terrorism, various types of challenges to human security and new types of warfare; but perhaps the greatest challenge is not to the community as such but to the values on which the system is based, and thus one of the greatest problems is 
managing the predominance of 'American hegemony' (Cottey 2007, 32). The continuers are well aware of the two major potential contradictions within the European security community: the tension between its identity and preferred practices and those of the American component of the system; and the divergence between the war-making essence of NATO (although constrained by its initial defensive character) and its evolution towards more of a political-military alliance system. As the Common Foreign and Security Policy (CFSP) is increasingly articulated, the tensions could be exacerbated; but this is to assume that the norms of the EU as a peace building project come to predominate. It is quite conceivable that the enlargement process and the neighbourhood policy, rather than expressing the pacific norms of the original EU, could become subject to a reverse adaptation: Europeanisation could give way to militarisation, albeit with a European face.

This, certainly was the fear of what we can call the 'innovators', with Russia in the van, who argue that the institutions designed to guarantee Europe's security in the Cold War are inappropriate for the new era. Indeed, the innovators argue that the instruments of security have paradoxically become the source of tension and conflict, and ultimately provoked the cold peace. At the minimum, Russian critics argue that Europe has failed to stand up for its own interests, and instead allowed itself to be subsumed into an Atlanticism that ultimately undermines its proclaimed values (Karaganov (ed.) 2008). Thus instead of acting as an independent subject, the European security system has fallen prey to the hegemonic aspect of the international order. It is for this reason that Russia proposed a new security system to supersede the post-war system, to to achieve a type of mark-2 Kellogg-Briand pact. Medvedev's call for a new European security treat (later dubbed Helsinki-2 or Helsinki-plus) in Berlin on 5 June 2008 reflected this aspiration. This is a classic instance of Russia assuming the role of innovator.

\section{Neo-revisionism}

Russia's inventiveness, however, takes a distinctive form. The tensions accompanying the search for a new relationship between Russia and what is conventionally called the West gave rise ultimately to a growing clamour for innovation, which in Russia takes the form of neo-revisionism. Russia makes no claim to revise the existing international order, but in a paradoxical inversion of the original Helsinki process, demands that the leading powers abide by the mutually-established rules of the international system, as well as claiming a leading place in that system. It is for this reason that Russia is far from being a consistently revisionist power, accompanied by balancing strategies to counter the hegemonic powers, but neither is it resigned to permanent bandwagoning. It is this unstable and complex middle path that shapes Russia's policy. It is ready (for the time being at least) to endorse American hegemony, as long as what it perceives to be its vital interests and prestige are recognised, accompanied by attempts to 'flatten' what is perceived to be the exaggerated prominence of the post-Cold War hegemonic constellation.

The attempt by outsiders to break in to the core of an existing hegemonic order has historically been accompanied by wars, which in the end have accelerated power shifts both within the hegemonic system and in relations with the challengers (Hurrell 2007). Germany and Japan were challenger powers from the late nineteenth century, a role now 
played by China. The first two ultimately became overtly revisionist powers, while China's 'quiet rise' disguises any revisionist ambitions that it may have. Russia today is not 'an emerging power' in the traditional sense, and thus its putative rise has less of a revisionist character (MacFarlane 2006, 43). Russia does not challenge the existing world order, but only the place accorded to it in that order. It wishes not to destroy the existing constitution of international society but to modify it in a way that would give Russia what is perceived to be its due weight and to ensure that the hegemonic powers apply their normative declarations to themselves (Sakwa, 2011, from which this section draws).

This was precisely the issue which prompted Putin's outburst at the Munich Conference on Security Policy on 10 February 2007. Putin's speech revealed deep disappointment that his attempts to engage with the West had been treated so superciliously. He stressed the 'universal, indivisible character of security' and warned against the dangers of establishing a 'unipolar world ... in which there is one master, one sovereign' while noting 'those who teach us [about democracy] do not want to learn themselves'. Putin listed a range of strategic problems, including the marginalisation of the UN, failure to ratify the adapted Conventional Forces in Europe (CFE) Treaty (initially signed in Paris between members of NATO and the Warsaw Pact on 19 November 1990, with the adapted version signed at the Organisation for Security and Cooperation in Europe (OSCE) summit in Istanbul on 19 November 1999), the remilitarisation of Europe through missile defence development, NATO enlargement that represented 'a serious provocation that reduces the level of mutual trust', the weakening of the non-proliferation regime and the attempt 'to transform the OSCE into a vulgar instrument to promote the foreign policy interests of one or a group of countries' (Putin 2007). The speech reflected the disenchantment of the Russian leader that the West appeared to dismiss Russian concerns as illegitimate and acted with a reckless impunity (as in the invasion of Iraq in March 2003) that now provoked Russia's backlash.

This was accompanied by the reassertion of a specific understanding of sovereignty, both at home and abroad. Vladislav Surkov, the chief ideologue of the Putin system, defined sovereign democracy as 'a form of political life of society, under which the authorities, their organs and actions are selected, formed and directed exclusively by the Russian nation in all its variety and completeness so that all citizens, social groups and peoples comprising it achieve material well-being, freedom and justice...' (Surkov 2007, 31-32). This stresses the autonomous character of Russian democratic development (drawing, however obliquely, on a type of Schmittean decisionism); but at the same time there is a second theme implicit in the message: the autonomy of the regime from society. In that respect, sovereign democracy perpetuates the thinking behind the 'managed democracy' that was characteristic of Putin's first presidential term. At the heart of both concepts is the view that democracy is an evolutionary process, and the revolutionary view of a leap to democracy based on the mechanical application of Western norms, which is framed as having been typical of the first post-communist decade, is rejected. Addressing a conference of United Russia activists on 7 February 2006, Surkov stressed that sovereign democracy was more than an abstract concept but the basis for praxis (Surkov 2006). Thus sovereign democracy espouses a view of autonomous mimetic learning and adaptation; but the failure to substantiate the implied programme of the development of appropriate Russian institutions of citizenship and political representation 
reduces mimesis to mere mimicry, leading to the development of a form of 'imitation democracy' (Furman 2008).

Expectations of an easy transition from one type of historicity and spatiality to another in the post-communist era were disappointed. Instead, Russia entered into a period of intensified liminality, accompanied by a pervasive sense of victimhood. In his annual report on the work of the government, delivered to parliament on 20 April 2011, Putin talked about the effects of the economic crisis, which he insisted came to Russia from outside:

The lesson all of us should learn is that economic and government weakness and susceptibility to external shocks inevitably threaten sovereignty. We all know very well that, let's be honest, if you are weak, there will always be someone who will be eager to advise you on where to move, which policy to pursue and which development path to choose. These seemingly friendly and unobtrusive recommendations may look good, but in point of fact they camouflage diktat and gross interference in the affairs of sovereign states. We are perfectly aware of this (Putin 2011b).

The Putinite narrative suggests that the crisis have been the result of Western bad faith and a consistent refusal to take Russia's legitimate interests and concerns into account. There is something in this, but clearly it is an inadequate account and fails to encompass Russia's own contradictions in engaging with the values it propounds. The recognition of Abkhazia and South Ossetia may have been forced on 26 August 2008, yet even as a response to the recognition of the Kosovan declaration of independence in February of that year it entailed a deviation from Russia's own state sovereignty discourses. Equally, Russia's fitful implementation of the obligations that it freely assumed on joining the Council of Europe, above all the independence of the judiciary to defend individual rights, can be laid at no-one's door other than its own. Putinite victim discourses are used instrumentally to consolidate a regime whose own legitimacy was increasingly challenged, especially because of the manipulation of electoral outcomes.

Traditional liberalism has long understood that free elections and other institutional arrangements of representative democracy require an adequate social and economic context to be able to work effectively (Gellner and Cansino (eds) 1996). Anything else can be termed, to use Anatol Lieven's phrase (2007), 'democratism', an analogy he draws with the 'actually existing socialism' of the Brezhnev and Honecker years. The concept of sovereign democracy, which as we have seen was devised during the Putin presidency in the mid-2000s to emphasise Russia's autochthonous path to democracy, at least had the merit of recognising the problem of mechanical adaptation, but when tempered by the heavy-handed managerialism of 'managed democracy', its domestic emancipatory potential was vitiated. All that remained was its external aspect, notably resistance not only to American liberal internationalism but also to a particular way of thinking about two issues in particular: the assumption that the interests of a particular state are synonymous with universal morality and needs; and that democracy can be disembedded from a particular context and imposed (by force if necessary) from outside. The Iraq adventure was evidence enough of the latter proposition. 
It has now become a platitude to argue that American democracy promotion has been used as a way of pursuing American policy to suit its interests, and in particular as a means not only to attack Russian foreign policy independence, but also quite overtly as an instrument in the struggle for mastery over former Soviet space (cf Barany and Moser 2009). Sovereign democracy is thus a riposte to American democratic evangelism and to the concept of democratism, but it is inadequately balanced by the development of authentic forms of domestic democratic political integration. The interaction of international dynamics and domestic development are always complex, but reaching back to Kozyrev's management of foreign policy it is clear that in post-communist Russia the dialectic has been particularly intense. Whether Russia would have developed differently if the West had been more amenable to Russian concerns remains a moot point. Obama's reset did allow Medvedev's modernisation agenda to flourish, but ultimately the failure to reform the administrative system, accompanied by Putin's return to the presidency in 2012 (an event about which America scarcely bothered to hide its distaste), was driven by domestic factors.

Russia's neo-revisionism is more than mere ressentiment, reflecting the hurt of the weak and the outcast, but frustration that the international society as constituted at the close of the Cold War had been unable to adapt to the new circumstances. Without the Soviet Union to restrain them, the hegemonic powers now behaved with hubristic messianism, or so it seemed to Moscow, and thereby undermined the principles that were so loudly proclaimed to lie at the core of their model of international society. Karaganov calls this the weakening of 'self-deterrence', the constraints that were placed on the behaviour of the Western powers by the mere existence of the Soviet Union as an alternative pole in the international system. As he puts it, 'When Russia was temporarily disabled and could not present a serious threat of escalation, self-deterrence softened, and the US ran off the rails', doing things that were unthinkable before, such as bombing Yugoslavia (twice, in 1995 and 1999) without a UN mandate (Karaganov 2011).

To that extent, Russia has emerged as the defender of a pluralistic world order based on the norms of international society as they had developed in the post-war years. It is this agenda that lies at the core of Russia's neo-revisionism. Buoyed by energy rents from the mid-2000s, Russia's policy undoubtedly became more assertive, but it was not overtly aggressive in the sense of wanting to change the existing balance of power in the international system. The five-day war with Georgia in August 2008 can be seen in this light, as Russia's response to the threat of NATO enlargement to Georgia and Ukraine. Equally, the policy does not exclude engagement, as occurred following Obama's 'reset' of relations with Russia in 2009. Russia remains a joiner, in that its membership of the Council of Europe and other normatively-driven international organisations is not in question, and after an arduous process at last joined the World Trade Organisation (WTO) in December 2011.

Despite much commentary to the effect that Russia wishes to be a 'norm-maker' and not just a 'norm-taker' (Haukkala 2008), my model of neo-revisionism suggests that this exaggerates the challenge contemporary Russia poses to the existing norms of international society. Russia remains a status quo power, but its claim to be a normenforcer and not just a norm-taker challenges the hegemonic powers to subordinate themselves to their own norms. The essence of Russia's neo-revisionism lies not in generating a new set of norms but resides in the sphere of practical diplomacy, where its 
foreign policy autonomy (and of other rising powers) constrains the freedom of manoeuvre of the old dominant constellation. Russia does not advance any substantive new norms to govern international order, but it consistently insists that the existing rules have to be obeyed by all powers, great and small. ${ }^{4}$ This may well be a traditional 'weapon of the weak', but is no less effective for that.From a status quo power Russia claimed to be a norm-enforcer and not just a norm-taker. Russia does not advance any substantive new norms to govern international order, but it consistently insists that the existing rules have to be obeyed by all powers, great and small. The essence of neorevisionism is not the attempt to create new rules or to dangle a vision of a new international order, but to ensure the universal application of existing norms in at most a modified international system. As far as Russia was concerned, the Georgian war demonstrated the systemic degradation of the post-Cold War order and the reassertion of geopolitical contestation. The Bush presidency was accompanied by great power rivalry, the militarisation of international politics and the structural erosion of the postcommunist peace accompanied by elements of a post-ideological Cold War, what is called in this article a cold peace (for the tone of the period, see Lucas 2008; also Bugajski 2004).

There is a more profound element in the contemporary stalemate between innovation and continuation, cooperation and antagonism. The new twenty years' crisis emerges out of the very nature of the anti-revolutions of 1989-91. These revolutions repudiated the logic of what went before, and not just the facts of the previous era, but have not generated a substantive agenda of their own. Instead, the 'return to Europe' posited the uncritical (mechanical) adoption of the existing Western structures of domestic and international order. This satisfied the long-term aspirations of the conformist powers of Eastern Europe, happy to be part of the West's continuation agenda, but it could not be an appropriate strategy for contestatory Russia. It is for this reason that the learning process in Russia remains imitative and lacks an Aristotelian mimetic character. As far as its elites were concerned, the ontological basis for a new 'normality' based on mechanical integration with the leading institutions of contemporary Western modernity, the EU and NATO, were absent. However, Russia's attempts to generate an alternative adaptive strategy encountered bewilderment in the West, provoked in part by astonishment that the triumphant Western 'normality' should be challenged at all.

Thus, Russia has inconsistently yet persistently tried to revise the international order, but without repudiating substantively the grounds of that order. Russia has called for the creation of a European security system no longer based on NATO; the reservation of a certain 'privileged' status in post-Soviet Eurasia; defended versions of 'sovereign democracy' in its neighbours, notably Belarus, Ukraine and Kazakhstan, based on an ideology of legitimism; launched a 'soft power' campaign in the West based on certain normative assertions, managed by a range of public affairs consultancies; questioned not only the efficacy but also the legitimacy of the OSCE and its institutions, particularly its

\footnotetext{
${ }^{4}$ This was repeated in various forms at the time of western intervention in Libya from March 2011. As Putin noted in his 'crusader' speech on 21 March 2011, which was broadcast on RT, 'I am worried about the ease with which decisions are being made to use force in international affairs nowadays', reproduced in CEPS, European Neighbourhood Watch, Issue 69, March 2011, p. 6 .
} 
election-monitoring agency; and intervened forcefully in Georgia in 2008 to put a halt to NATO enlargement. Much of this was defensive and reactive, yet the kernel of an alternative vision of world order is tangible. Russia began to outline the ontological grounding for an alternative 'normality'. However, the lack of a substantive ideational basis for this alternative reveals the structural constraints keeping Russia trapped in the neo-revisionist complex: neither fully a member of the Western community but neither its systemic antagonist.

Russian neo-revisionism does not challenge the fundamental postulates of the international system based on a systemic or ideological critique, and neither does it consistently challenge the existing rules of the international game. It does not propose the full-scale revision of contemporary practices and principles, many of which it was (in its Soviet or Russian guise) a constitutive associate. Thus Russia is a permanent member of the Security Council, a privilege that it seeks neither to renounce nor dilute. Equally, Russia was a founder member of the increasingly ramified Helsinki process, although it has certainly become a critic of some of the practices of the OSCE. This brings us fullsquare to the ontological basis of neo-revisionism: Russia's perception that the norms and institution of contemporary international order have been 'privatised' by a group of leading states, and in a restatement of Carr's classical paradigm, particular interests are pursued in the guise of universal principles. The universalistic postulates of Wilsonian idealism once again come up against particularistic concerns.

\section{The problem of universalism}

Universalism is the process that in contemporary international politics is epitomised by the adoption in 1948 by the United Nations of the Universal Declaration of Human Rights. The Soviet Union, like much of the Islamic world, was profoundly ambiguous about the Declaration, considering it largely as the concretisation of western values, yet ultimately signed up. The universalistic agenda received a massive boost in the Final Declaration of the Helsinki Conference on Security and Cooperation in Europe (CSCE) in August 1975. The Soviet Union and its allies were forced to accept the 'third basket' agenda of human rights in exchange for the benefits of baskets one (mutual recognition of existing borders and a range of confidence building measures) and two (economic goods). The Helsinki principles were thereafter used by human rights activists in the Soviet bloc as a measure against which the behaviour of their governments could be measured, notably in the Charter 77 movement in Czechoslovakia and the various Helsinki monitoring bodies in the USSR and elsewhere.

\section{Neo-revisionism as a critique of teleological universalism}

The cold peace demonstrates once again the power of symbols and the social imaginary. The original Cold War intensified the pressure to conform and revere the symbols of American democracy, notably the constitution, and enforced a range of allegianceintensifying social practices, exploited to the full by Senator Joseph McCarthy and the House Committee on Un-American Activities in the early 1950s. The Cold War in the popular imagination was more than an international policy to constrain a threatening

power but became part of a crusade to defend the American way of life, democracy and 
the free world. The roots of this lie in Woodrow Wilson's interventionist liberalism even before he became president, in response to the Mexican revolution and and America's intervention. Wilson's ideational leadership fused the export of democracy and American geopolitical interests. The Cold War accentuated these features, to the point that Hartz could talk about 'liberal absolutism' (Hartz 1955). The symbolic dimension of international politics was vividly illustrated by the Truman administration's exaggerated and demonstrative use of the term 'totalitarianism' (Gleason 1995, 81). The aim was to blacken its protagonist and hence enhance its own status as the singular exemplar of civilisational totality. The spread of the ideology of democracy became part of the state's global mission, and with its allies joined in a global crusade to defend and advance a set of civilisational values (Rossbach 1999).

Although post-communist Russia is ostensibly a child of the Helsinki process, with the 1990 Charter of Paris the manifesto of post-communism in the region and many of the drafters of the Russian constitution were activists in the Helsinki tradition, Russia today is highly ambivalent about the whole Helsinki experience. This sustains the neorevisionist critique of the practices of the dominant powers in the international system. While the Yeltsin leadership in the 1990s sought to make what had become in 1994 the OSCE the premier security organisation on the continent and endorsed the work of its various agencies, including the Office of Democratic Institutions and Human Rights (ODIHR) based in Warsaw, today (as mentioned) Russia seeks to revise 'Helsinki 1' in some sort of 'Helsinki Plus' process. The aim was to universalise universalism.

This is the model advanced by Carl Schmitt in 1950 in a book whose full title is: The Nomos of the Earth in the International Law of the Jus Publicum Europaeum. The work extols the virtues of the Westphalia order, a 'spatial, political and legal order (the 'nomos of the earth') embodied in the jus publicum Europaeum', which in his view underwent a process of dissolution since the end of the nineteenth century to the First World War. The book anticipated the dangers that arose from the 'hegemonic global interventionism of the United States of America, the effects of de-concretisation and universalisation of international law (that is, of 'order' without explicit spatial grounding), of diminishing pluralism in the international system, as well as the evolution of partisan warfare and terrorism' (Odysseos and Petitio 2007, 1). Key terms include the bracketing of war (thus opposed to just war theory); the Monroe Doctrine of 1823 and a different form of political subjectivity, reflected in American ideas of Grossraum (greater space); and the journey from isolationism to (Wilsonian) universalism, accompanied by today's 'humanitarian interventionism'. As Odysseos and Petitio put it in their introduction to the work, 'liberalism attempts to turn the pluriverse of international politics into a universe, in which the effects of difference are controlled from a "metasovereign" site through current US-driven attempts to reformulate international law by conferring a special status on liberal democracies, as well as by reintroducing a "discriminatory concept of war" in the form of a right to different forms of intervention to preventive ones' (Odysseos and Petitio 2007, 13).

Today this takes the form of an enhanced sense of normative superiority, reinforced by alleged victory over the protagonist in the Cold War. Raymond Geuss notes the strong Kantian taint to contemporary international politics. 'This strand', he writes, 'expresses itself in the highly moralised tone in which some public diplomacy is conducted, at any rate in the English-speaking world, and also in the popularity among 
political philosophers of the slogan "politics is applied ethics". He stresses the "slickly ambiguous' nature of such a view. On the one hand, politics is not a value-free sphere of activity and hence judgement and 'ethics' are intrinsically bound up in human interactions (the 'anodyne reading' according to Geuss) (Geuss 2008, 1). However, the 'applied ethics' approach in his view is objectionable because of its attempt to implement an 'ideal theory' of ethics, separate from real life, based on the Kantian view that ethics can be entirely non-empirical, based completely on 'the mere notion of rational agency, and the absolute consistency of willing that is purportedly the defining characteristic of any rational agent. Kantian ethics is supposed to be completely universal in its application to all agents in all historical situations' (Geuss 2008, 7). Geuss sums up his view as follows: 'The view I am rejecting assumes that one can complete the work of ethics first, attaining an ideal theory of how we should act, and then in a second step, one can apply that ideal theory to the action of political agents' (Geuss 2008, 8).

Geuss's alternative is based on four principles for political philosophy: it should be realist (p. 9); it should recognise that politics is above all about 'action and the contexts of action' (p. 11); that politics is historically located (p. 13); and, finally, that politics 'is more like the exercise of a craft or art, than like traditional conceptions of what happens when a theory is applied' (p. 15). This is in effect an Aristotelian mimetic theory of international ethics, a historically grounded learning process based on reciprocity rather than a one-dimensional exercise in geopolitical pedagogy. In practice this would entail, for example, America pursuing a policy that puts American interests first in its relations with Russia rather than seeking to mould Russia to some predetermined policy or normative agenda. Ethics are not thereby jettisoned (the crude understanding of an interest-based foreign policy) but are applied in an 'anodyne' manner, respecting the subjectivity of others while upholding their own normative values. Ethics are not thereby jettisoned (the crude understanding of an interest-based foreign policy) but their 'anodyne' application, respecting the subjectivity of other while upholding in a Geussian way its own normative values.

\section{From universalism to 'pluriversalism'}

The global 'civil war' between 1917 and 1989 only occluded the fundamental tension, which has emerged so starkly in the post-Cold War era, between universalism and pluralism. In internal politics, as Chantal Mouffe $(1999,2005)$ and others long argued, the unchallenged Anglo-American hegemony stifled 'the political', the ability of real problems to find agonistic forms of discourse in the public sphere; and on the global scale this has distorted the practice of 'the international', and instead seeks to impose a 'preordered' form of hegemony. The respatialisation of the international arena, as advanced by the idea of 'sovereign democracy', gives valance to a range of political actors, above all states, who are no longer ranked in terms of their relationship with the hegemon, but which can now substantiate alternative forms of engagement with the 'civilisation of modernity', to use Eisenstadt's term $(2001,325)$. The revalorisation of a multiplicity of actors entails the revival of 'the political' at the level of 'the international'. This provokes a crisis of world order, in which Russia is the main protagonist of a different 'nomos of the earth', what it calls multi-polarity but which in Schmittean terms is a pluriverse. This meta-view of international affairs tempers and shapes interactions in all aspects of 
Russia's foreign policy and provides the theoretical grounding for the concept of the contemporary cold peace.

The post-communist era is based on the logic of a fundamental asymmetry: the active repudiation of one set of principles and the passive acceptance of another. Sheldon Wolin $(2008,37)$ notes the process of 'anticommunism as mimesis: the character of the enemy supplied the norm for the power demands that the democratic defender of the free world chose to impose on itself'. A 'superpower' is defined by Wolin (p. 40) 'as an imaginary of power that emerges from defeat unchastened, more imperious than ever'. The 'War' in the abstract has been declared, while the reality of great power rivalry is occluded (Wolin, 2008, 31). It is this period that is now coming to an end, a time whose demise was hastened by Russia's emergence as a neo-revisionist state, accompanied by fundamental shifts in the balance of world power. Russia's attempt to devise a neorevisionist path between being a passive norm-taker and an aggressive norm-maker takes the form of presenting itself as a norm-enforcer.

Russia's insistence on respect for the traditional repertoire of international law, above all adherence to territorial and governmental sovereignty is vitiated by its own behaviour, but this behaviour is not based on the consistent presentation of a set of alternative norms. Russia constitutes itself not as a separate 'order' but seeks to contribute to the creation of a more genuinely 'pluriversal' international society, consisting of different and equally legitimate systems. The degree to which it is a consistent practitioner of the nomos that it proclaims is of course questionable, and in certain respects Russia reproduces the tropes of its mimetic competitors. It thus constitutes itself as a counter-hegemonic power operating in the manner of its protagonist.

The debate is a fundamental one and can be couched in terms of a tension between Weberian and Durkheimian approaches to political order. For the Weberian, reflected in the Putinite model of state reconstitution, the emphasis is on asserting 'the monopoly over legitimate use of force within a given territory' (a classical sovereigntycentred model of political authority) accompanied by the imposition of bureaucratic uniformity and rational administration. The Durkheimian approach, by contrast, emphasises the values and character of the regime, and thus feeds into liberal discourses on the importance of equal and inclusive citizenship, precluding the arrogation of tutelary sovereignty by the administrative regime. Iver Neumann argues for the crucial importance of this variable, as well as the quality of governance (couched by him in terms of the practices of governmentality). In particular, he argues, the Russian state is reluctant to relinquish its direct imposition of power over society, and hesitates to accept a liberal dynamic of a self-managing society working indirectly with the state (Neumann 2008). It is precisely at this point that the incommensurable nomoi of universalism and pluriversalism in international affairs collide.

This helps contextualise current debates about Russia's relations with external actors. Some of the most interesting work in analysing Russia's relations with the EU is based on the idea of competing rationalities (Averre 2008). This could be couched in traditional terms as the logic of competing interests, with the interests themselves reflecting the socio-economic characteristics of the state, its elite structure and selfrepresentation. The competing political rationalities approach finesses the stale juxtaposition of a tension between 'values' and 'interests' and opens up fruitful terrain 
for investigation. However, the notion of political rationality has to be grounded in some theoretical context, and clearly the classic one is the Weberian approach. We are here not dealing so much with his classic threefold categorisation of traditional, charismatic and legal-rational forms of political legitimacy within a state, but the rationality that a state or nascent political subject (like the EU) as a complex system of orders exhibits in its interaction with other subjects of the international system. Any system of rationality is embedded in representations of the system in which they operate. As far as Russia is concerned, there is not one international order but many, what we label the pluriverse view but which in classic Primakovian terms of the 1990s was known as multipolarity.

Both Russia and the EU (and the West in general), from this perspective, represent different but equally legitimate political logics; and by extension, both the continuer and innovator viewpoints are perfectly rational strategies. It is their fundamental incompatibility that provokes the cold peace. At a different level, this is captured by Nye's view of different 'narratives' of power (Nye 2011); what in Foucauldian terms could be considered discourses. Russia is making proposals not just about the management of global governance, but specifically about European governance, focused not just on the EU's 'external governance' agenda, but on Europe itself as a multiverse. In this arrangement the EU has to share continental space with Russia and Turkey, and some other smaller powers; and by doing so, changes the EU's identity in a fundamental manner. No longer can it present itself as the only peace project in Europe, or its model of governance as the only rational one but is forced to come to terms with Europe's re-emergence as a microcosm of multipolarity. This represents a geopolitical shift with profound implications as the EU, Russia and Turkey are forced to find new forms to manage the return of multipolarity in Europe, no longer based on great powers alone but on possibly incommensurate political projects..

In recognising the Schmittean subjectivity of others and asserting its own, there can however be no return in this pluriverse to a nineteenth century world of clearly delineated competing great powers. The notion of 'order', a relatively stable set of relations between states, and 'governance' issues, cannot simply trump the constructivist view of the mutual recognition and constitution of identity and difference. Equally, the tension between civilisational issues, defined as different cultural perspectives on sovereignty and legitimacy, and diplomatic 'realist' ambitions remain central to foreign policy management, even if shaped by the larger vision of 'the international'. The civilisational perspective does not necessarily see Russia locked in a permanent contest with other social formations; yet it does suggest a particular character to the international that informs the operation of universal norms. The neo-revisionist agenda gives Russia's distinctive engagement with the civilisation of modernity substance and character that complements those generated in the West. It is a mimetic strategy with the potential to transform the mechanical appropriation of existing universalist agendas into organic adaptation through plural representations of international order. In other words, contemporary actors may transcend the mimetic cold war to establish a genuine warm peace; but the continued application of ethicised hegemonic strategies could provoke the return of the Cold War to international politics.

\section{Conclusion: liminality and mimesis}


Post-Cold War asymmetries have provoked a permanent crisis in Russo-Western relations, with debilitating effects in post-Soviet Eurasia. The crisis takes institutional form in the continuing debate between continuers and innovators. The post-Cold War era remains liminal, in the sense that no stable new order has been established to which all the parties are committed. On the one side, Russia is certainly not a fully-fledged revisionist power. The basis for its new assertiveness is not an attempt to change the normative basis of the existing world order, but the claim that its equal participation in that system has not been fully acknowledged. The existing system, from the point of view of the innovators, is considered to embody a fundamental asymmetry: the extension of a system devised for one purpose - to contain the USSR and to advance the norms of the Western alliance system - into a new era and new territories, a temporal and spatial extension that generates tension rather than extending security.

In the post-communist era Russia tried to adapt to a normality that is itself in crisis, a crisis that is exacerbated by Russia's critique of that normality. Russia represents a parallel sphere where the conscience and bad faith of our era are played out, both in terms of its critique of contemporary international order, and also in its contradictory application of that critique. The contemporary international system is based less on a 'liberal peace' than on the structural power of the hegemonic system. This naturally generates resistance, which so far does not go beyond the neo-revisionism of the cold peace but contains the potential for systemic conflict. This is accompanied in Russia by an intensified demand on the past to provide legitimacy and the ordering principles for the post-communist present. Lacking a basis in the present, there is an intensified demand on the past to provide legitimacy and the ordering principles for the post-communist present. This provokes attempts to revalorise important aspects of the communist past, and that is why the struggle over history textbooks and the politics of memory have become so critical in Russian public discourse, and, more generally, why discourses of victimhood have become so central in the reconstituted national narratives of so many post-communist states. It is not temporal issues, however, that are is the ultimate source of the cold peace, but incommensurable representations of geopolitical space. Russia's 'revolt' against Western hegemonic institutions has fostered some profound debates about pluralism in the international system and some ideas for their modification. Its critique, however, is not grounded in a developed vision of an alternative order, like some reasoned new secondworldist project, and thus Russia is a neo-revisionist power rather than an out-and-out revisionist force. Russia's relationship with the West has thus become mimetic, adapting to the normality practised there while simultaneously subjecting it to a critique that nevertheless fails to generate a substantive alternative. Russia's relationship with the West has thus become mimetic, adapting to its normality while simultaneously subjecting it to a critique that fails to generate a substantive alternative. Typically, Russia's critique only strengthens the West, which is a fundamental characteristic of mimetic power.

At the boundaries of the structured forms of West European civilisation, Russia is an uncomfortable member of the club of European powers. The formal end of the Cold War in 1989-91 did not put an end to profound cultural and civilisational ambiguities in Russia's relations with the West, and these took the form of a cold peace. This was exacerbated by the residual 'crusader' structure to the thinking of key Western states. The context had clearly changed, and with it the modalities of struggle: but the practices of a global enlargement of the values embedded in the dominant hegemonic formation 
remained. This took on new rhetorical forms, notably a renewed emphasis on human rights and democratic elections, and in certain respects broadened out to become more of an inclusive process. Some of the hard axiological edge of the Cold War era was dropped, and the aim now was to facilitate the passage of former adversaries into the community of the just. For most of the former eastern European communist countries this provided a welcome opportunity to reorient their policies and ultimately they became part of the expanded Western community. However, the process was far from unproblematic in post-Soviet Eurasia, where it encountered civilisational resistance and problems of mimetic adaptation. Out of this emerged the cold peace; but it also provides grounds for the transcendence of the cold peace.

\section{References}

Anderson, Perry (2010) 'Two Revolutions: Rough Notes', New Left Review, 61, Jan-Feb, 59-96

Asmus, Ronald (2010) A Little War that Shook the World: Georgia, Russia and the Future of the West (Basingstoke, Palgrave Macmillan)

Averre, Derek (2008) 'Russian Foreign Policy and the Global Political Environment', Problems of Post-Communism, 55: 5, 28-39

Barany, Zoltan and Robert G. Moser (eds), Is Democracy Exportable (Cambridge, Cambridge University Press)

Bugajski, Janusz (2004) Cold Peace: Russia's New Imperialism (Santa Barbara, CA, Greenwood Press)

Carr, E. H. (2001) The Twenty Years' Crisis, 1919-1939: An Introduction to the Study of International Relations, Reissued with a New Introduction and additional material by Michael Cox (London, Palgrave, [1939])

Clunan, Anne L. (2009) The Social Construction of Russia's Resurgence: Aspirations, Identity, and Security Interests (Baltimore, Johns Hopkins University Press)

Cornell, Svante E. and S. Frederick Starr (eds) (2009) The Guns of August 2008: Russia's War in Georgia (Armonk, NY \& London, M. E. Sharpe)

Cottey, Andrew (2007) Security in the New Europe (Basingstoke, Palgrave Macmillan)

'Diplomats Shocked by Kozyrev Ploy' (1992), The Independent, 15 December, p. 9.

Eisenstadt, Shmuel N. (2001) 'The Civilizational Dimension of Modernity: Modernity as a Distinct Civilization', International Sociology, 16: 3, 320-340 
Finkel, Evgeny (2010) 'In Search of Lost Genocide: Historical Policy and International Politics in Post-1989 Eastern Europe', Global Society, 24: 1, 51-70

Freire, Maria Raquel and Roger E. Kanet (eds), Key Players and Regional Dynamics in Eurasia: The Return of the 'Great Game' (Basingstoke, Palgrave Macmillan, 2010)

Frye, Timothy (2010) Building States and Markets after Communism: The Perils of Polarized Democracy (Cambridge, Cambridge University Press)

Furman, Dmitri (2008) 'Imitation Democracies: The Post-Soviet Penumbra', New Left Review, 54, November-December, 29-47

Gellner, Ernest and Cesar Cansino (eds) (1996) Liberalism in Modern Times: Essays in Honour of José G. Merquior (Budapest, Central European University Press)

Geuss, Raymond (2008) Philosophy and Real Politics (Princeton and Oxford, Princeton University Press)

Gleason, Abbott (1995) Totalitarianism: The Inner History of the Cold War (New York and Oxford, Oxford University Press)

Gorlizki, Yoram and Oleg Khlevniuk (2004) Cold Peace: Stalin and the Soviet Ruling Circle, 1945-1953 (New York, Oxford University Press)

Greenleaf, Monika and Luba Golburt (2009) 'Introduction' to special issue on 'Copies: The Mimetic Component of Remembering', Slavic Review, 68: 4, 743-57

Hamilton, Robert (2009) 'The Bear Came Through the Tunnel: An Analysis of Georgian Planning and Operations in the Russo-Georgian War and Implications for US Policy', in Paul B. Rich (ed.), Crisis in the Caucasus: Russia, Georgia and the West (London, Routledge), 202-234

Hartz, Louis (1955) The Liberal Tradition in America: An Interpretation of American Political Thought since the Revolution (New York, Harcourt and Brace)

Haukkala, Hiski (2008) 'A Norm-Maker or a Norm-Taker? The Changing Normative Parameters of Russia's Place in Europe', in Ted Hopf (ed.), Russia's European Choice (Basingstoke, Palgrave Macmillan), 35-58

Hosking, Geoffrey (1997) Russia: People and Empire 1552-1917 (London, Harper Collins)

Hurrell, Andrew (2007) On Global Order: Power, Values, and the Constitution of International Society (Oxford, Oxford University Press) 
Ikenberry, G. John (2001) After Victory: Institutions, Strategic Restraint, and the Rebuilding of Order after Major Wars (Princeton, NJ, Princeton University Press

Karaganov, Sergei (2008) 'Novaya epokha', in Sergei Karaganov (ed.), Rossiya i Mir Novaya Epokha: 12 Let, Kotorye Mogut Vse Izmenit' (Moscow, AST, Rus'-Olimp), 4264

Karaganov, Sergei (2011) 'Preodolet' ’sderzhivanie”?', Rossiiskaya gazeta, 6 April, p. 6

Kopeček, Michal (ed.) (2008) Past in the Making: Historical Revisionism in Central Europe after 1989 (Budapest \& New York, Central European University Press)

Korinman, Michel and John Laughland (eds) (2008) Russia: A New Cold War? (Edgware, Middlesex, Vallentine Mitchell Publishers)

Kozyrev, Andrei (1995) 'Partnership or Cold Peace?’, Foreign Policy, 99, Summer, 3-14.

Lieven, Anatol (2007), 'In the Sweep of History: Where Realists and Progressives can Meet', Boston Review, July-August 2007;

http://bostonreview.net/BR32.4/article_lieven.php

Lucas, Edward (2008) The New Cold War: How the Kremlin Menaces both Russia and the West (London, Bloomsbury)

MacFarlane, Neil S. (2006) 'The "R" in BRICs: Is Russia an Emerging Power?', International Affairs, 82: 1, 41-57

Mouffe, Chantal (1993) The Return of the Political (London, Verso)

Mouffe, Chantal (2005), On the Political (London, Routledge)

Neumann, Iver B. (2008) 'Russia as a Great Power, 1815-2007', Journal of International Relations and Development, 11, 128-51

Nye, Joseph S. (2011) The Future of Power: Its Changing Nature and Use in the Twentyfirst Century (New York, Public Affairs).

Odysseos, Louiza and Fabio Petitio (2007) 'Introduction: The International Political Thought of Carl Schmitt', in Louiza Odysseos and Fabio Petitio (eds), The International Political Thought of Carl Schmitt: Terror, Liberal War and the Crisis of Global Order (London, Routledge)

Ortmann, Stefanie, 'Great Power Images and the Russian State under Putin and Medvedev', in Vadim Kononenko and Arkady Moshes (eds), Russia as Network State (Basingstoke, Palgrave Macmillan), Chapter 6 
Prozorov, Sergei (2006) Understanding Conflict between Russia and the EU: The Limits of Integration (Basingstoke, Palgrave Macmillan)

Putin, V. V. (2007), 'Russian President Vladimir Putin's Speech at the 2007 Munich Conference on Security Policy', 10 February 2007, http://president.kremlin.ru/text/appears/2007/02/118109.shtml, accessed 15 March 2007.

Putin, V. V. (2011a) 'Predsedatel' pravitel'stva Rossii V. V. Putin predstavil v Gosudarstvennoi Dume otchët o deyatel,nosti Pravitel'stvo Rossiiskoi Federatsii za 2010 god', 20 April 2011, http://premier.gov.ru/events/news/14898/\#qq, accessed 27 April 2011

Putin, V. V. (2011b) 'Novyi integratsionnyi proekt dlya Evrazii - budushchee, kotoroe rozhdaetsya segodnya', Izvestiya, 4 October, p. 1

Rich, Paul B. (2009) 'Russia as a Great Power', in Paul B. Rich (ed.), Crisis in the Caucasus: Russia, Georgia and the West (London, Routledge), 26-49.

Rossbach, Stefan (1999) Gnostic Wars: The Cold War in the Context of Western Spirituality (Edinburgh, Edinburgh University Press)

Sakwa, Richard (2010) Russia and Turkey: Rethinking Europe to Contest Outsider Status, Russie.Nei.Visions No. 51, Paris, IFRI Russia/NIS Center, May, pp. 21. Available at www.pearltrees.com/ifri.russie.nei/651883/>

Sakwa, Richard (2011) 'Russia and Europe: Whose Society?', in Ioannis Stivachtis and Mark Webber (eds), 'Europe After Enlargement', special issue, The Journal of European Integration, 33: 2, 197-214

Shevel, Oxana (2011) 'Russian Nation-building from Yel'tsin to Medvedev: Ethnic, Civic or Purposefully Ambiguous?', Europe-Asia Studies, 63: 2, 179-202

Shevtsova, Lilia (2010) Lonely Power: Why Russia Has Failed to Become the West and the West is Weary of Russia (Washington, D.C., Carnegie Endowment for International Peace)

Surkov, Vladislav (2006) 'Suverenitet - eto politicheskii sinonim konkurentosposobnosti', in Nikita Garadzha (ed.), Suverinitet (Moscow, Evropa), 43-79.

Surkov, Vladislav (2007) 'Natsionalizatsiya budushchego', in Suverennaya demokratiya: Ot idei k doktrine (Moscow, Evropa), pp. 27-44.

Suzuki, Shogu (2008) 'Seeking "Legitimate" Great Power Status in Post-Cold War International Society: China's and Japan's Participation in UNPKO', International Relations, 22: 1, 45-63 
Sztompka, Piotr (1998) 'Devenir social, néo-modernisation et importance de la culture: quelques implications de la révolution anticommuniste pour la théorie du changement social', Sociologie et sociétés, 30: 1, 85-94.

Tsygankov, Andrei P. (2007) 'Finding a Civilisational Idea: "West", "Eurasia", and "Euro-East" in Russia's Foreign Policy', Geopolitics, 12, 375-99

Tsygankov, Andrei P. (2008) 'Self and Other in International Relations Theory: Learning from Russian Civilisational Debates', International Studies Review, 10: 4, 762-75

Tsygankov, Andrei P. (2012) 'Russia, Europe and the Idea of Honor: From the Holy Alliance to the Policy of Receuillement', International Studies Quarterly

Tsygankov, Andrei P., (2012) Russia and the West from Alexander to Putin: Honor in International Relations (Cambridge, Cambridge University Press).

Wolin, Sheldon S. (2008) Democracy Incorporated: Managed Democracy and the Specter of Inverted Totalitarianism (Princeton, Princeton University Press) 